\title{
IMPROVED CAPABILITIES OF MANAGERS SLAUGHTERHOUSE IN SAVING EPIDIDYMIS SPERMATOZO, SUPPORTING FOOD SOVEREIGNTY
}

\author{
Maya D. D. MAHARANI \\ Environmental Engineering, Sahid University, Indonesia \\ maya@usahid.ac.id
}

\begin{abstract}
Spermatozoa collected from epididymis cauda can be used as an alternative source of gametes in the application of reproductive technologies, because the spermatozoa has motility and the ability to fertilize oocytes. Rescuing Epididymis Spermatozoa (ES) in cattle after slaughtering in Ruminant-Slaughterhouses (R-S) is a real action reduce the import of cattle, and saving the germplasm of native Indonesian cattle. This Community Service paper communicates skills and capabilities of Slaughterhouse Managers about ES rescue. Community Service conducted in 2019, located in 2 R-S (Bogor, Depok). Problem solving is done through informal education and discussion, consultation with reproductive expert and direct practice of taking genitals. Knowledge Improvement, and skills of R-S Bogor Manager better compared to Depok in ES rescue. The skills of R-S Bogor Manager in the selection and retrieval of testicles are neater, so that the resulting quality of ES meets the criteria good anatomically of testicles. Reflective practice can be said to be an effective way to improve skills. It is proven that one of the participants (User R-S) not R-S Manager ventured to establish R-S in Purwokerto, Central Java and ready to carry out the rescue of ES
\end{abstract}

Keywords: capabilities, manager-slaughterhouse, epididymis-spermatozoa, rescue

\section{BACKGROUND}

According to data from the Ministry of Agriculture of the Republic of Indonesia in 2021, the number of livestock slaughter facilities in Indonesia as many as 693 (six hundred and ninety-three) units. Of these, most of the livestock slaughter facilities, do not have enough water sources and the state of supporting facilities is very concerning, so the ideal conditions expected from the Ruminant-Slaughterhouse (R-S) function can not be said to be optimal. Similarly, the number of human resources that is still minimal includes veterinarians, paramedics and halal slaughterers who are certified by the Indonesian Ulema Council (MUI), especially in rph-r managed by the government is still limited in terms of quantity and quality.

The R-S built by the government has the aim of facilitating the slaughter of livestock to produce meat in accordance with the criteria of Safe-Healthy-Whole-Halal that is ready to be consumed by the community and traded or serves as a service or public service. Safe understanding is the use and conditioning of livestock products that do not contain biological, chemical and physical hazards that can interfere with human health, livestock or environmental functions. Healthy is the use and conditioning of livestock products that meet the nutritional criteria necessary for human health and do not contain disease seeds. The whole understanding is the payment and conditioning of livestock products that are not mixed with other products that are not similar. Halal understanding is the payment and conditioning of livestock products obtained in accordance with Islamic law.

From the identification of stakeholders participating in R-S include: (1) groups of livestock traders village or subdistrict or city-district or province or between provinces or between countries, (2) service users, (3) meat retailers, (4) the government, (5) the Indonesian Ulema Council (MUI), (6) Universities, (7) Development Research Institute, (8) importers and extension of their hands consisting of agents and sub-agents, as well as (9) household breeders. However, among the nine identified stakeholders actively participating, the group of cattle traders between regions who sometimes double as service users are the most powerful stakeholders participating, so the phenomenon that appears to dominate.

Different in the 1960s, the owner of interests who play an active role and finally have a tendency to dominate is livestock pejagal, because access to slaughtering facilities provided by the management of R-S service business unit is quite large. Cattle traders between regions consist of individuals who can have a permanent relationship to give birth to cooperation between them or with importers through agents and sub-agents, so they finally have a tendency to act as an extension of the hands of importers. Individual cattle traders between these areas are very strong to compete with each other. Those who become agents and sub-sub agents of the importers, get ease by the importer to get ready-toslaughtered livestock until the ease to get the criteria of how to slaughter ex-imported livestock.

Therefore, some of the behaviors of service users who are concurrently livestock traders, and the use of R-S infrastructure facilities are related to be considered in the social, economic, environmental, regulatory and technological dimensions in the management of $\mathrm{R}-\mathrm{S}$ service business units. This can be seen from the strong dynamics of service user groups that can raise international issues, among others, about animal welfare. In addition, it is suspected that the group of service users can trigger importers to ask the government to carry out a policy of importing beef cattle. The reason the group is more interested in ex-imported livestock is because the price is relatively cheaper than local livestock, the quality of ex-imported livestock is better, the continuity is more maintained, also the carcasses produced are greater than 50 percent, so the profit will be greater than if they slaughtered local livestock. 
The ban on slaughtering productive female animals has been encouraged by the government, so that the slaughter of female animals can be more controlled. The rules of slaughtering male animals have not been regulated, so many productive bulls that have good performance are wasted, whereas in the testicle, especially epididymis there are sources of genetic material that can still be used. One of the sources of genetic material of animals native to Indonesia is obtained in R-S both managed by the government in the form of institutional Regional Technical Implementation Unit (UPTD), Regional Owned Enterprises (BUMD) as well as private companies. The institution in carrying out its performance requires innovation and creativity as well as science and technology in managing animal slaughter services in a sustainable manner. One of the opportunities for innovation, creativity and science and technology that allows to be implemented is to utilize the structure of animal genetic material after it is slaughtered.

Spermatozoa collected from epididymis cauda can be used as an alternative source of gametes in the application of various reproductive technologies, because the spermatozoa has motility and has the ability to fertilize oocytes. Rescuing Epididymis Spermatozoa (ES) in animal after slaughtering in R-S is a real action to reduce the import of cattle, and saving the Germplasm of native Indonesian animals (Emma R et.al., 2020; Muslim Akmal et.al., 2015; Oktora Dwi Putranti, et.al., 2019).).

Slaughterhouses was one part of the livestock industry (Umi Salamah \& Retno Adriyani, 2018). The slaughterhouse also called an "abattoir", is a facility where animals are slaughtered and processed into meat products which safe, healthy, whole, halal (for Muslims). In large R-S facilities, slaughtering is carried out in fully mechanized lines (FAO, 2021). The workers are assigned to specific workstations and the carcasses move on a conveyor system from station to station until the slaughter process is completed. In slaughter line operations, clean and unclean operations are physically separated and individually manned to avoid contamination of carcasses and edible byproducts. The clean operations include evisceration, carcass splitting and carcass dressing. Slaughtering animals on a large scale poses significant problems in terms of logistics, animal welfare, and the environment, and the process must meet public health requirements.

In many developing countries adequate slaughter facilities are not available. At rural or local level slaughtering is often either carried out under a tree or in deteriorated and outdated slaughter units without any waste treatment facilities. This often results in health hazards through contamination of the meat during slaughter operations and of the surrounding land and water through uncontrolled release of waste and effluents. In rural settings slaughtering can be done in basic small-scale facilities. Before building a slaughtering facility a number of factors must be considered including the species to be slaughtered, expected slaughter numbers, environmental impact, the availability of a competent workforce and the linkages to the meat markets.
The results of the Indonesian Population Census in September 2020 recorded 270.20 million, and people needing meat which increases every year. According to (KumparanFood, 2020) the national beef consumption rate in Indonesia is currently an average of $2.9 \mathrm{~kg}$ per capita per year, so it takes the population of ready-to-slaughtered ruminant as much as 5-10 million ruminant (cattle) per year. Therefore, to provide ready-slaughtered cattle, Indonesia must have Human Resouces Slaughterhouse-Managers who have the capabilities and skill in the rescue of ES. The ES rescue technology is an attribute in the sustainability management of R-S (M D D Maharani et.al., 2017).

\section{METHOD}

\section{Preparation Stage}

This stage begins with the creation of activity proposals, discussions to R-S Managers and Users, Animal Traders, as well as consultation and coordination to Veterinary Reproductive Experts faculty of veterinary medicine Bogor Agricultural Institute (IPB).

\section{Implementation Stage}

The implementation is carried out with an educational approach, non-formal discussions, direct reflective practice to the Manager and R-S Service Users. Reflective practices can be said to be an effective way to improve skills (Kiron Koshy et.al., 2017). Reflective practice can greatly improve your skills. The discussion material is how to overcome the sometimes low price of imported cattle than the price of cattle native to Indonesia (Bali, Madura). As the result there is a scarcity of ready-toslaughtered cattle. Education and hands-on practice to ensure the rescue and preservation of ES can run smoothly due to technical assistance from Veterinary Reproduction Experts from IPB. The key component of ES rescue and preservation success is communicating with R-S Users and Managers, in addition to technical components. The others key components is the balanced right left testicle shape, so it will produce a good quality of fresh cement. The activity was attended by R-S manager, and R-S users of Bogor and Depok (Figure 1).

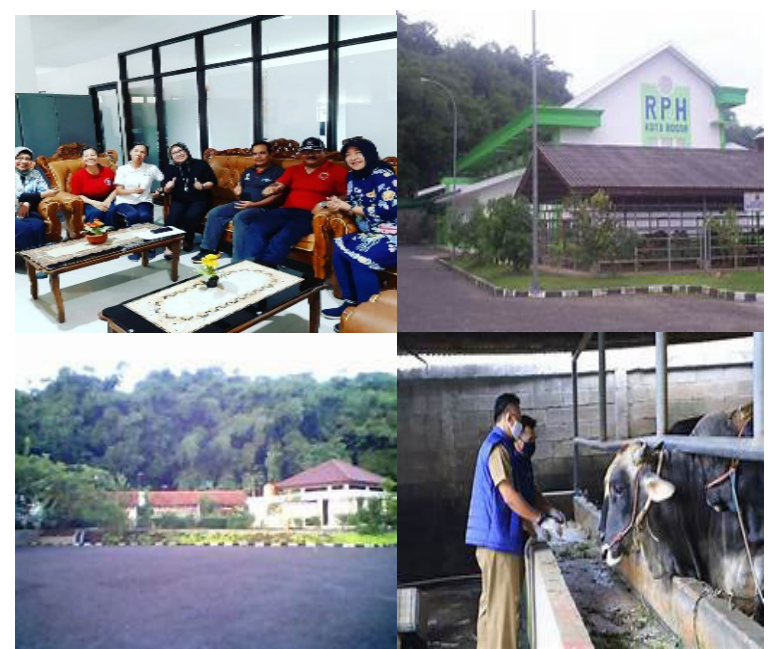

Figure 1. Photo of Ruminant-Slaughterhouse Bogor and Depok 
The process of implementation of the activity starts at 14.00 to $15.00 \mathrm{pm}$. While the practice is directly carried out at night according to the schedule of slaughtering animals starting at $23.00 \mathrm{pm}$ to $03.00 \mathrm{am}$.

\section{RESULT AND OUTPUT}

Knowledge Improvement, and skills of R-S Bogor Manager better compared to Depok in ES rescue. The skills of R-S Bogor Management in the selection and retrieval of testicles are neater, so that the resulting quality of ES meets the criteria good anatomically of testicles. Anatomically, the testicles and epididymis have a normal shape, good consistency. Epididymis stands out clearly, it can be interpreted that the testicles as the producer of gamete and epididymis as a warehouse / place to store spermatozoa function properly (Figure 2).

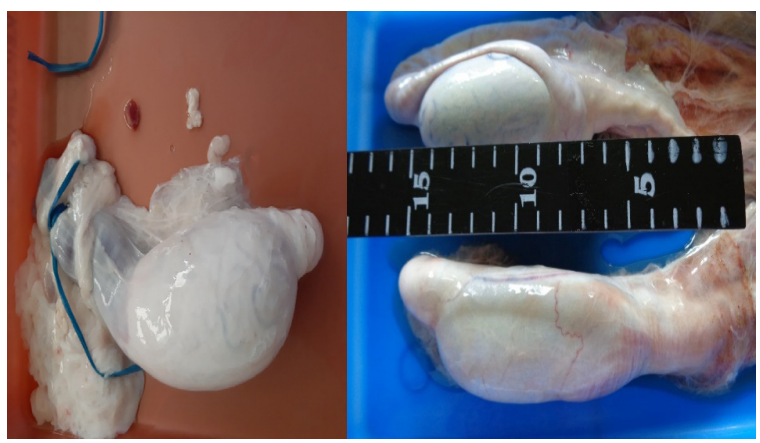

Figure 2. Photo of Testicles and Epididymis of Bali Cattle

Spermatozoa of Bali cattle obtained from R-S shows quite good quality (milky white). The motility of spermatozoa ranges from 30 to $75 \%$. Viability between 84.69 to $87.18 \%$. The concentration of spermatozoa is quite high between 2075 to 3050 million $/ \mathrm{ml}$.

Spermatozoa that exits the testicles and enters the epididymis is a spermatozoa that is not yet functional due to its low motility and oocyte fertilization ability. The incompetent spermatozoa produced by the testicles undergoes maturation and storage processes in the epididymis duct. Spermatozoa in each part of the epididymis have different characteristics due to morphological changes, especially in the head as well as the migration of cytoplasmic droplets. During the journey from kaput to corpus, cytoplasmic droplets move, from the head to the tail intermediate part then it will detach from the spermatozoa either through the fluid in the epididymis causal, during or after ejaculation, depending on the species. In addition, changes in the pattern or integrity of acrosom also occur along with the transit of spermatozoa in the epididymis.

Motility of spermatozoa has also developed on the kaput epididymis. A small percentage of spermatozoa in this part of the epididymis kaput begin to exhibit the ability to swim progressively and recognize oocytes. The concentration of spermatozoa in the kaput is $25-50 \times 10^{6}$. Spermatozoa on the epididymis kaput has cytoplasmic droplets on the proximal part. The characteristics of spermatozoa continue to develop from the epididymis kaput before reaching optimal levels in the distal causal part. The cytoplasmic droplets spermatozoa on the epididymis corpus have been translocated to the central region at the curve of the flagelum. The concentration of spermatozoa in the corpus is $8-25 \times 10^{9}$. Spermatozoa in this section already has the ability to perform zone bonding. Dilution material is an ingredient that is added to the cement to increase the volume of cement, reduce the concentration of spermatozoa and maintain the survival of spermatozoa for a certain time. Cement dilution solution that has a more complete chemical composition will provide a good function for diluted cement, because the substrates on the dilutor material are needed spermatozoa to maintain its life. Cement dilution material commonly used in Indonesia is Tris yolk consisting of Tris Hydroxy methyl aminometan, citric acid, fructose, egg yolk, penicillin, streptomycin, and aquabidest. Tris together with citric acid serves as a buffer to maintain $\mathrm{pH}$ changes due to the formation of lactic acid resulting from spermatozoa metabolism and plays a role in maintaining osmolarity pressure and electrolyte balance.

Abnormalities of primary spermatozoa (in the head) between 8.88 to $9.86 \%$. Secondary abnormalities are high enough to reach $80 \%$ namely the presence of residual cytoplasmic droplets or cyto plasmic droplets (Figure 3).

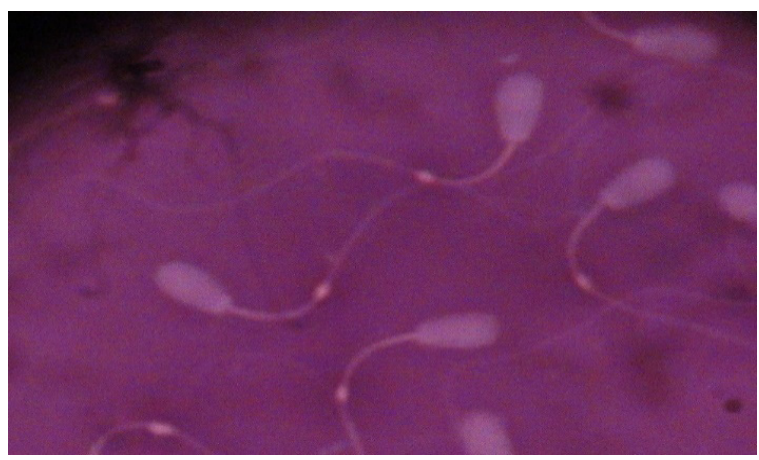

Figure 3. Photo of Secondary Abnormalities, Cytoolasmic Droplets (arrows) of Bovine Spermatozoa of Balinese Cattle Epididymis Origin

Reflective practice can be said to be an effective way to improve skills and capabilities. It is proven that one of the participants (User's R-S) ventured to establish R-S in Purwokerto, Central Java and ready to carry out the rescue of ES for Artificial Insemination (AI).

The Artificial Insemination facility called the National Artificial Insemination Center (NAIC) already built in Addis Ababa City, Kality, aimed at serving the community. Furthermore the Addis Ababa government has built four other semen and liquid nitrogen productions and distribution centers in four regional states. From these four AI technologies centers, one of them is instituted in Nekemte town, western Oromia, Ethiopia. The utilization of AI technologies in Nekemte semen and liquid nitrogen, production and distribution centre, to determine how this technology is performed and to identify and evaluate the challenges and opportunities to characterize AI technology. To implement ES rescue for AI, this technology procedure is required from the beginning of selection semen of bulls to 
the delivery of bred AI calves. During the procedure, after selection of bulls to breed and produce semen is passed through laboratory procedures requiring high engineering and effort in addition to liquid nitrogen production (Aklilu Biru et.al., 2018). The selection of bulls and their testicles is determined by their health status.

Attributes of animal health status in the ecological dimension in the management of $\mathrm{R}-\mathrm{S}$ is one of the leverage or leverage attributes with the Value of Root Mean Square (RMS) of 5.08. The meaning is that these attributes have a big influence on the sustainability index of ecological dimensions in the R-S service business management model on a sustainable basis. Similarly, the attributes of cement rescue and preservation technology with a value of RMS of 3.95 is one of the attributes included in the index of sustainability of the technology dimension in the R-S service business management model on an ongoing basis. The two attributes of animal health status and cement preservation rescue technology have a high association in the utilization of ES from native Indonesia cattle in R-S in support of food sovereignty in Indonesia (M D D Maharani et.al., 2015).

Bali and Madura cattle are native Indonesian cattle that have many advantages, including being easy to adapt to various types of feed and environmental conditions. Bali cattle can adapt to changing seasons as evidenced by the data on weaning weight, annual weight, and good reproductive conditions. Bali cattle are one of the types of beef cattle that have a fairly high carcass percentage, namely 51\% (H. Hafid, Nuraini et.al., 2018) to 54\% (Suryanto, E. et.al., 2017). Bali cattle also have the best productivity levels with low input values and good resistance to environmental stress. Good quality Balinese beef with low fat content (Sutarno \& Ahmad Dwi Setyawan, 2016). The reproductive efficiency of Bali cattle is classified as good with a service per conception $(\mathrm{S} / \mathrm{C})$ value of 1.76 to 1.84 (Suharyati et.al., 2016) with a conception rate (CR) of $80.00-86.67 \%$ (Mardiansyah et. al., 2016).

\section{EVALUATION}

Community service evaluation activities are carried out through coordination and face validity directly to the Head of Regional Technical Implementation Unit (UPTD) R-S Integrated Bogor City (Figure 4).

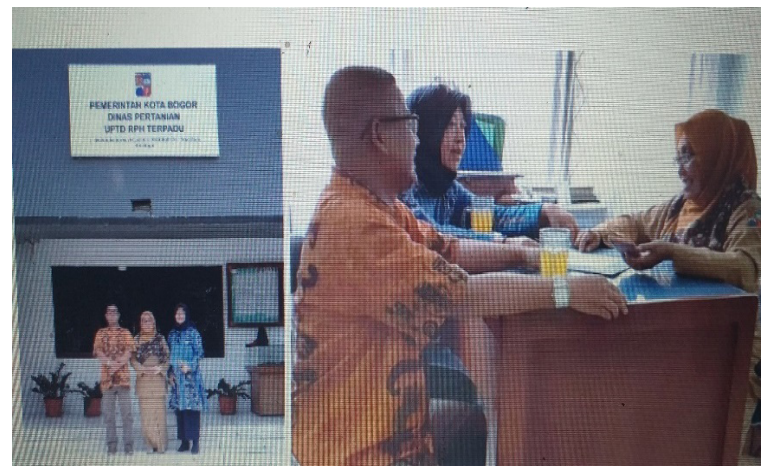

Figure 4. Photo of Coordination and face validity directly to the Head of Regional Technical Implementation Unit (UPTD) RPH Integrated Bogor City
Recommendations submitted to the Head of Regional Technical Implementation Unit (UPTD) RPH Integrated Bogor City (Ir. Dwi Dasawati, MM), among others, propose additional mini reproductive laboratory facilities, recruit AI technicians, and AI officers. From the economic dimension, a pair of testicles are commonly sold worth ( $\operatorname{Rp} 30.000$,- up to Rp 50.000,-), if intervened with the use of ES will produce as many as 80 straws or 80 prospective cows. This value has the potential to the revenue of R-S service business and in turn can increase the Regional Native Income, or if done through the movement of utilization of all R-S then it does not close the possibility of food sovereignty program (meat) can be achieved.

\section{CONCLUSION}

The structure of genetic material from animals or livestock either for breeding or reproducible purposes, captive breeding of wild or non-wild animals can be lost at any time, caused by: (1) accidental or severed death, (2) slaughtered in R-S, (2) unexpected death, (3) low libido, or (4) the occurrence of reproductive disorders. Efforts can be made in the use of preservation of genetic material because it is wasted or gamete rescue, rescue and preservation of the structure of genetic material from male animals that have died after being slaughtered in R-S, namely by the utilization of ES. It will be necessary Manager's R-S skills and capabilities in ES rescue. Manager's R-S Bogor skills and capabilities in ES rescue is better than Depok. R-S infrastructure facilities and infrastructure need to be equipped with a mini laboratory, so that the sustainability of rescue skills and the preservation of ES rescue can be achieved. Reflective practice method is an important part of skills, capabilities and progression, if done well, can improve skills as a R-S Manager in ES rescue. The successful use of ES for AI technology is the collaboration and communication between R-S Managers and the government through the Ministry of Agriculture, so that incentive and reward policies can motivate AI technicians. It is hoped that the government will wise on the livestock sector to increase overall state revenues and improve the livelihoods of R-S and others stakeholders (user R-S, cattle ranchers).

\section{ACKNOWLEDGEMENT}

I would like to thank for:

1. Community Service Research Institute of Sahid University Jakarta, Indonesia

2. Head of Reproductive Laboratory of Faculty of Veterinary Medicine IPB

\section{REFERENCES}

Aklilu Biru, Zelalem Abera, Misgana Duguma and Ayantu Hundera. 2018. Review on Procedures and Utilization of Artificial Insemination Technologies in Nekemte Semen and Liquid Nitrogen Production 
and Distribution Centre, Western Oromia, Ethiopia. ConDai \& VetSci 1(4)-2018.CDVS.MS.ID.000117. DOI: $\quad$ 10.32474/CDVS.2018.01.000117.https:// lupinepublishers.com/dairy-veterinary-sciencejournal/pdf/CDVS.MS.ID.000117.pdf

Emma R. James, Douglas T. Carrell, Kenneth I. Aston, Timothy G. Jenkins, Marc Yeste, and Albert Salas-Huetos (2020). "The Role of the Epididymis and the Contribution of Epididymosomes to Mammalian Reproduction.”.International Journal Molecular Sciences., 21(15), 1-17

FAO. 2021. Slaughtering Facilities. http:/www.fao.org/ AG/AGAINFO/themes/en/meat/slaughtering.html

H. Hafid, Nuraini, Inderawati, and W. Kurniawan (2018) "Bali cattle carcass Characteristic of Different Butt Shape Condition”. IOP Conf. Series: Earth and Environmental Science 119 (2018) 012043. Doi:10.1088/1755-1315/119/1/012043

KumparanFood. 2020.Tingkat Konsumsi Naik, Daging Sapi Kini Tak Lagi Jadi Makanan Mewah di Indonesia. https://kumparan.com/kumparanfood/ tingkat-konsumsi-naik-daging-sapi-kini-tak-lagijadi-makanan-mewah-di-indonesia-1u5Yg8hB801

Kiron Koshy, Christopher Limb, Buket Gundogan, Katharine Whitehurst, and Daniyal. J. Jafree. 2017. Reflective practice in health care and how to reflect effectively. Internasional Journal Surg Oncol (NY), 2(6): e20. doi: 10.1097/IJ9.0000000000000020

Mardiansyah, E. Yuliani, dan S. Prasetyo (2016) "Respon tingkah laku birahi, service per conception, non return rate, conception rate pada sapi Bali dara dan induk yang disinkronisasi birahi dengan hormon progesteron.”. Jurnal Ilmu dan Teknologi Peternakan Indonesia, 2: 134-143
M D D Maharani, Sumardjo, Eriyatno, Eko Sugeng Pribadi (2017). "Strategi Pengelolaan Usaha Jasa Rumah Pemotongan Hewan Ruminansia Secara Berkelanjutan (Management Strategy For Sustainable Ruminant-Cattle Slaughterhouse (RCS) Services).”. Jurnal Veteriner,18(1), 94-106

M D D Maharani, Sumardjo, Eriyatno, Eko Sugeng Pribadi (2015). "Structural Model for Sustainable Management of Ruminant Cattle Slaughterhouse (RC-S): The Establishehment and Renovation of RC-S.”. Journal Global Veterinaria, 14(5), 707-719

Muslim Akmal, Dian Masyitah, Hafizuddin, Fitriani (2015). "Eididimis Dan Perannya Pada Pematangan Spermatozoa.”. JESBIO, IV(2), 1-6

Oktora Dwi Putranti, Lovita Adriani, Soeparna, Tita Damayanti Lestari (2019). "Effect of Caffeine on Motility of Epididymis Spermatozoa of Bali Bull in Slaughterhouse Cibinong.". Chalaza Journal of Animal Husbandry, 4(2), 44-47

Suharyati, Sriand Hartono Madi(2016)"Pengaruh Manajemen Peternak Terhadap Efisiensi Reproduksi Sapi Bali Di Kabupaten Pringsewu Provinsi Lampung.”. Jurnal Penelitian Pertanian Terapan, 16(1), 61-67

Suryanto, E., Bulkaini, B., Soeparno, S., Karda, I.W. (2017) "Carcass Quality, marbling, Meat Cholesterol and Non Carcass Component of Bali Cattle Fed With Fermented Cacao Shell. Bull.”. Ani. Sci. 41, 72-78

Sutarno, Ahmad Dwi Setyawan (2016) "Review: The diversity of local cattle in Indonesia and the efforts to develop superior indigenous cattle breeds.", BIODIVERSITAS, 7(1), 275-295

Umi Salamah, Retno Adriyani (2018). “Analisis Risiko Kesehatan Pekerja Di Rumah Pemotongan Hewan Akibat Pajanan Gas Amonia.”. Jurnal Kesehatan Lingkungan, 10(1), 25-35 